\title{
COX-2 expression in fibroblast aggregates as a functional indicator for the anti-inflammatory activity of leukemia patients' bone marrow-derived hematopoietic cells
}

\author{
K. EGYUDOVA ${ }^{1, \star}$, M. FAJTOVA ${ }^{1}$, A. CIZMAR ${ }^{2}$, M. KORHONEN ${ }^{3}$, J. GYARFAS ${ }^{4}$, E. KANKURI ${ }^{5}$, J. BIZIK ${ }^{1}$
}

${ }^{1}$ Cancer Research Institute, Slovak Academy of Sciences, Bratislava, Slovakia; ${ }^{2}$ University Children's Hospital, Department of Paediatric Oncology, Bratislava, Slovakia; ${ }^{3}$ Finnish Red Cross Blood Service, Helsinki, Finland; ${ }^{4}$ National Cancer Institute, Department of Hematology, Bratislava, Slovakia; Institute of Biomedicine, Pharmacology, University of Helsinki, Finland

${ }^{*}$ Correspondence: katarina.egyudova@savba.sk

Received February 1, 2012 / Accepted April 13, 2012

\begin{abstract}
Reciprocal communication between hematopoietic cells and their surrounding bone marrow stroma is crucial for normal progression of hematopoiesis. This complex network of cell-to-cell signals in the microenvironment involves both cell contactmediated and paracrine cues. In hematological malignancies the intricate balance is, however, disrupted to support cancer progression. In order to detect altered microenvironmental reactivity of a hematopoietic cell sample, cellular functional assays can be designed to measure the cells' capacity to modulate stromal stress reactions, such as inflammation.

Recently, we showed that human leukemic cell lines of monocytic origin can actively participate in modulation of stromal inflammation. In order to further functionally evaluate the hematopoietic cells' capacity to modulate stromal inflammation, we utilized an in vitro model of nemosis-induced inflammation of fibroblasts in a three-dimensional culture setting. This process of stromal inflammation in fibroblast aggregates is consistent, requires both cell-contact and paracrine signals, and can be produced on a large scale to support dose-dependent analyses. To extend our previous observations, we evaluated the effect of a wide panel of leukemia cell lines on cyclooxygenase- 2 induction in fibroblast aggregates in co-culture. We also assessed the feasibility of the model to support clinical functional testing by utilizing the hematopoietic fraction of leukemia patients' bone marrow aspirates after immunophenotyping. Our results suggest that the stromal inflammation-modulating activity of these samples is differently modulated in cancer and in normal bone marrow. Moreover, differences in the samples' anti-inflammatory activity may reflect disease state.
\end{abstract}

Key words: human leukemia, inflammation, nemosis, cyclooxygenase- 2

Reciprocal communication between hematopoietic cells and their surrounding microenvironment-stroma is crucial for normal progression of hematopoiesis [1]. The control network of soluble and insoluble signals regulates both stromal responses and differentiation of hematopoietic precursors, as well as, maintains the stem cell pool. Unfortunately, also malignant cells utilize this intricate signaling system for the promotion and progression of leukemogenesis [2]. In the inflammatory "cancer microenvironment", the malignant cells and their stroma are nourished by various growth factors and cytokines [3]. Inflammation has been shown to promote the tumor cells' survival, proliferation, and metastatic activity, as well as, to increase their resistance to chemotherapeutic agents. On the other hand, it is not well known under which circum- stances and how the malignant cells modulate or upkeep the inflammatory process for their needs.

In the present study we analysed the ability of the hematopoietic cell fraction, either isolated from leukemia patients' bone marrow (BM) samples or as cell lines, to modulate stromal inflammation in vitro. To enable functional testing of those cellular processes that govern the signal-regulatory network in the cancer's aseptic inflammatory microenvironment, we utilized a fibroblast model of cell-to-cell contact and paracrine signaling-induced inflammation, nemosis. This process is effectively induced in dermal fibroblasts [4-6], and is characterized by a massive induction of cyclooxygenase- 2 (COX-2) that serves as a sensitive marker for inflammation. Moreover, nemosis-activation of fibroblasts has been shown to 
be associated with production of several cytokines associated with inflammation e.g. IL-1, IL-6, IL-8; cell growth factors like HGF, amphiregulin, and FGF7, as well as, inducers of differentiation: IL-11, LIF, and GM-CSF [5,7,8]. Although this mixture of cytokines is similar to that produced by stromal cells isolated from BM [9] and we have shown bone marrow stromal cells (BMSCs) to react in a similar manner upon aggregation [10], fibroblast reactivity is preferred for sensitive functional in vitro testing due to the prompt and prominent induction of COX-2.

The present study was based on our previous observations showing that human leukemic cells can modulate inflammation in fibroblast aggregates as assessed by dose-dependent suppression of COX-2 expression [11]. Although the previously analysed three cell lines were all able to downregulate COX-2 expression, they significantly differed in their potency. In this study, we further extended this analysis of human leukemic cell lines. Moreover, we also tested human hematopoietic cells isolated from BM and peripheral blood of leukemic patients for their ability to modulate this cell-contact and soluble mediator-induced inflammatory activation of fibroblasts.

Our results extend the profile of human leukemic cell lines to modulate stromal inflammation in terms of mesenchymal COX-2 expression. We show here that this co-culture method is also usable for patient samples, and the cells for the assay can be isolated from the same BM aspirate that is also used for flow cytometry immunophenotyping of hematological malignancies.

\section{Materials and methods}

Antibodies. Antibodies used for immunoblotting were: goat anti-COX-2 primary antibody (Ab) (sc-1746, Santa Cruz Biotechnology, CA) and anti-goat alkaline phosphataseconjugated (V115A, Promega, Madison, WI) secondary Ab. Antibodies for flow cytometry (FACS) were: anti-CD45phycoerythrin (anti-CD45-PE, 555483, BD Biosciences, San Jose, CA), and anti-CD20-allophycocyanin (anti-CD20-APC, 340908, BD Biosciences).

Cell cultures. Human dermal fibroblasts (MUF 7/1) established from human neonatal foreskin were kindly provided by Dr. Miroslav Pirsel (Cancer Research Institute, Bratislava, Slovakia), and were used from passages 5 to 15 . Analysed human leukemic cell lines were as follows: THP-1, acute monocytic leukemia [12]; KG-1, acute myelogenous leukemia [13]; U-937, histiocytic lymphoma [14]; HL-60, acute promyelocytic leukemia [15]; ML-2, acute myeloid leukemia [16]; MOLM-9, chronic myelogenous leukemia [17]; Jurkat, acute T cell leukemia [18]; Daudi, Burkitt's lymphoma [19]; Ramos, Burkitt's lymphoma [20]; K-562, chronic myelogenous leukemia [21]; NALM-16, acute lymphoblastic leukemia [22]; U-698, lymphosarcoma [23].

The fibroblasts and all leukemic cell lines were cultured in RPMI 1640 supplemented with 10\% fetal bovine serum, 50
$\mathrm{IU} / \mathrm{mL}$ streptomycin, and $50 \mu \mathrm{g} / \mathrm{mL}$ penicillin (all from Life Technologies, Gibco, Carlsbad, CA).

Patient samples. BM cells were derived from bone marrow aspirates from the posterior iliac crest of BM transplantation donors and from patients suspected of or diagnosed with a hematological malignancy. The source of patient material used for experimentation was clinical specimen obtained from the Department of Paediatric Oncology, University Children's Hospital and National Cancer Institute, Bratislava. Samples from healthy donors were from the University of Helsinki Central Hospital, Children's Clinic, Helsinki, Finland and were taken for research purposes. The material used for each assay was the leftover material of the aspirate after diagnostic flow cytometry. BM hematopoietic and stromal cells were isolated by density gradient on Ficoll-Pague ${ }^{\mathrm{TM}}$ Plus (GE Healthcare Bio-Sciences AB, Uppsala, SE). Differential adhesion was employed to separate mesenchymal stromal cells from hematopoietic cells. All samples were collected and processed with permission of the Human Ethics Committee of the National Cancer Hospital, Bratislava.

Formation of fibroblast aggregates (spheroids). Spheroid formation was initiated as described previously [4]. Briefly, Ubottom 96-well plates (Costar, Cambridge, MA) were treated with $0.8 \%$ LE agarose (BioWhittaker, Rockland, ME) prepared in sterile water to form a thin film of non-adhesive surface. Fibroblasts were detached from culture dishes by trypsin/EDTA, and a single cell suspension $\left(4 \times 10^{4}\right.$ cells $\left./ \mathrm{mL}\right)$ was prepared in complete culture medium. Thereafter $250 \mu \mathrm{L}$ aliquots were seeded into individual wells, and the dishes were incubated at $+37^{\circ} \mathrm{C}$ in $5 \% \mathrm{CO}_{2}$ atmosphere. Cell numbers were counted using a Bürker chamber.

Co-culture of hematopoietic cells and fibroblast spheroids. For co-cultivation experiments the leukemic cell lines or the non-adherent fraction of BM was used $24 \mathrm{~h}$ after its isolation. The cells were placed in 96-well plates treated with agarose at indicated concentrations. Fibroblasts were added to each well, and the co-cultures were incubated for the next $72 \mathrm{~h}$. Fibroblast spheroids were separated by gravitational differential sedimentation, and analysed for COX-2 expression by immunoblotting. Isolated non-adherent cells were also analysed for COX-2 expression before and after co-cultivation.

Immunoblotting. Cells were washed with PBS, and lysed in reduced sample buffer $(62.5 \mathrm{mmol} / \mathrm{L}$ Tris- $\mathrm{HCl}(\mathrm{pH} 6.8)$, $2 \%$ SDS, 20\% glycerol, 5\% $\beta$-mercaptoethanol and 0.005\% bromophenol blue) supplemented with protease inhibitors (Complete Miniprotease Inhibitor Tablets, Roche, Germany), and incubated at $+95^{\circ} \mathrm{C}$ for $5 \mathrm{~min}$. Lysates were centrifuged at $3000 \mathrm{rpm}$ for $5 \mathrm{~min}$ to sediment particulate-insoluble material. Each sample separated by SDS-PAGE (gradient of polyacrylamide $5-15 \%, 3.5 \%$ stacking gel) was then transferred to a nitrocellulose membrane (Schleicher\&Schuell, Dassel, Germany) in transfer buffer at $150 \mathrm{~mA}$ during $18 \mathrm{~h}$. Transfer efficiency was verified by Ponceau-S staining. After blocking in $2.5 \%$ low-fat dry milk in TBS $(20 \mathrm{mmol} / \mathrm{L}$ Tris- $\mathrm{HCl}, 150 \mathrm{mmol}$ $\mathrm{NaCl}, 0.1 \%$ Tween-20, $\mathrm{pH} 7.5$ ) the membrane was incubated 

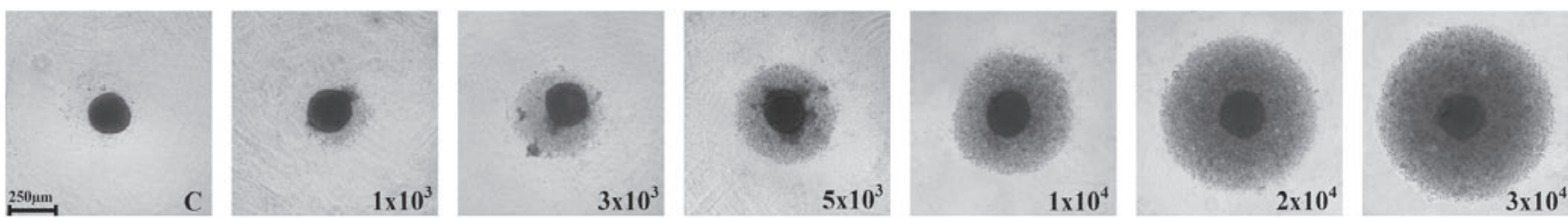

Figure 1. Phase contrast microscopy showing co-cultivation of series of non-adherent hematopoietic cells isolated from bone marrow aspirates with spheroids. Dense structure in the centre is the spheroid formed from MUF 7/1 dermal fibroblasts $\left(10^{4}\right.$ cells/well) and halo structure around individual spheroid is created by a portion of non-adherent cells at indicated numbers $\left(1 \times 10^{3}, 3 \times 10^{3}, 5 \times 10^{3}, 1 \times 10^{4}, 2 \times 10^{4}, 3 \times 10^{4}\right.$ cells/well $), C$ - represents control, uninfluenced spheroid. Scale bare is $250 \mu \mathrm{m}$.

with primary antibodies followed by the secondary alkaline phosphatase-conjugated antibody. Visualization of protein bands was carried out with the Pierce NBT/BCIP western blotting substrates according to manufacturer's recommendations (Thermo Fisher Scientific, Rockford, IL). IC I0 $_{50}$ values were calculated using the non-linear curve-fitting algorithm in GraphPad Prism version 5 (GraphPad Software, La Jolla, CA) as specified in our previous study [11].

Flow cytometry. After standard cultivation or after cocultivation with spheroids, the hematopoietic non-adherent cell fraction was analysed by flow cytometry. The cells were incubated on ice with anti-CD45-PE, and anti-CD20-APC, and FACS analysis was performed by FACS Canto II flow cytometer (BD Biosciences, San Jose, CA). Data was analysed using Cyflogic program, version 1.2.1.

Statistic. Statistical significance was calculated using a twosided Mann U Whitney test due to small sample size, and $\mathrm{p}<0,05$ was set as significant.

\section{Results}

Using the methodological approach as described in our recent study [11], we evaluated the anti-inflammatory activity

Table 1. Summary of mean $\mathrm{IC}_{50}$ values estimated for analysed leukemic cell lines. The introduced $\mathrm{IC}_{50}$ value represents an average obtained from three independent experiments. The values marked with $\left({ }^{\star}\right)$ were adopted for comparison from our previous study [11]. the characteristics of the cell lines were taken from Drexler, 2000[24].

\begin{tabular}{lllc}
\hline \multicolumn{2}{l}{ Cell line designation } & Representing cell type & $I_{50}$ value \\
\hline 1. & HL-60 & promyelocyte & 3453 \\
2. & KG-1 & myelo-monocyte & $3519 *$ \\
3. & ML-2 & myelo-monocyte & 1030 \\
4. & MOLM-9 & myeloblast & 2835 \\
5. & THP-1 & monocyte & $746 *$ \\
6. & U-937 & myelo-monocyte & $921 *$ \\
7. & Daudi & B-lymphoblast & 8626 \\
8. & Jurkat & T-lymphocyte & 10003 \\
9. & K-562 & B-lymphocyte & 3034 \\
10. & NALM-16 & B-lymphocyte & 19692 \\
11. & Ramos & B-lymphocyte & 8852 \\
12. & U-698 & B-lymphocyte & 5891 \\
\hline
\end{tabular}

of 6 myelo-monocytic and 6 lymphoblastic cell lines. To initiate the co-culture, the leukemic cells were seeded at a density of $1 \times 10^{3}-3 \times 10^{4}$ cells/well, and a constant amount of dermal fibroblasts $\left(1 \times 10^{4}\right.$ cells/well) was added (Fig. 1). Fibroblast spheroids were separated and harvested when maximal COX-2 induction was reached after $72 \mathrm{~h}$ of co-culture. $\mathrm{IC}_{50}$ values were calculated by densitometric analysis of COX-2 band intensity on immunoblots. $\mathrm{IC}_{50}$ represents the amount of co-cultured leukemic cells that reduces COX-2 expression in fibroblast spheroids to half when compared to COX-2 expression in spheroids alone. The $\mathrm{IC}_{50}$ values calculated for the leukemic cell lines are summarized in the Table 1 . As reference the $\mathrm{IC}_{50}$ values estimated for the three cell lines in the previous study are presented. The $\mathrm{IC}_{50}$ values of myelo-monocytic cells were in the range between 746 (THP-1) to 3519 (KG-1), and the mean $\mathrm{IC}_{50}$ value for all six myelo-monocytic cell lines was 2084. In general, the lymphoblastic cell lines exhibited lower capacity to inhibit COX-2 expression than the myelo-monocytic cells. IC $_{50}$ values for lymphoblastic cell lines ranged from 3034 (K-562) to 19692 (NALM-16), and the mean IC $_{50}$ value for these cells was 9350 . Taken together, the cells of lymphoblastoid origin were thus 4.5 times less potent to inhibit COX-2 expression in comparison to the cells of myelo-monocytic origin.

Because the assay is based on the evaluation of COX-2 expression in fibroblasts co-cultivated with leukemic cells, it was necessary to exclude any contribution to the levels of COX-2 by tested leukemic cells. We therefore assayed all leukemic cell lines for COX-2 expression before and after their co-cultivation with fibroblast spheroids. None of the cell lines was positive for COX-2 expression (data not shown). We detected COX-2 expression only in the HEL erythroleukemia cell line, which was thus excluded from this study.

We then isolated hematopoietic cells from the unused portions of bone marrow aspirates after immunophenotyping. Mesenchymal cells were separated after gradient centrifugation by adherence to plastic, and the non-adherent hematopoietic fraction was used for further analyses. Careful depletion of mesenchymal cells was necessary because of their natural anti-inflammatory properties [25] even when representing less than $1 \%$ of the total population. Although we observed changes in the morphology and composition of the samples after 7 days in culture, the most important fact for the established assay was proved by FACS analysis (as 


\section{0. day}

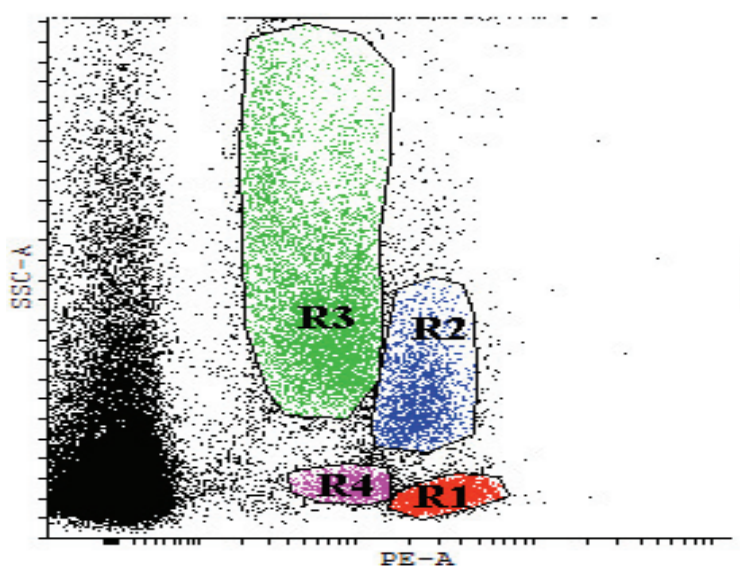

1.day

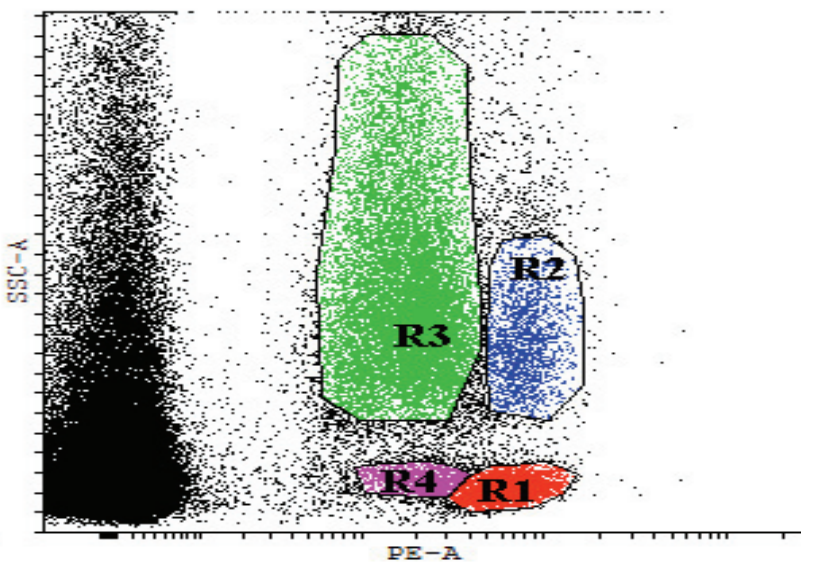

Figure 2. FACS analysis of non-adherent fraction isolated from a bone marrow sample. The analysis was performed in order to compare composition of interface portion obtained from the specimen of AML patient \# 19 after cultivation for $24 \mathrm{~h}$. The first analysis (0. day) was performed immediately after density gradient separation and the second one (1. day) after $24 \mathrm{~h}$ incubation in culture. Marked subpopulations represent: R1 - lymphocytes, R2 - monocytes, R3 - granulocytes, R4 - pathologic cell population. The CD45-PE antibody was used for the analysis.

demonstrated by the representative Fig. 2) showing similarity of the composition of the interphase fraction derived from bone marrow before and after a 24-hour incubation, suggesting that these cells could be employed for the assay. Moreover, this enabled us to carry out the adherence-depletion step with the non-adherent population still remaining representative of that in the fresh sample.

We then evaluated the effect of sample culturing time on the COX-2 inhibitory activity of isolated non-adherent cells. Aliquots of cells derived from patient \#19 were added to cocultures with spheroids at different time points after their isolation ( $24 \mathrm{~h}, 72 \mathrm{~h}, 144 \mathrm{~h}$ ). $\mathrm{IC}_{50}$ was 3731 for cells that were used for analysis $24 \mathrm{~h}$ after isolation, whereas it was 4791 and 5315 for the same cells analysed at time points $72 \mathrm{~h}$ and $144 \mathrm{~h}$, respectively (Fig. 3). Prolonged cultivation of non-adherent cells of another patient with acute myeloid leukemia (AMLM7) showed similar decline of inhibitory activity. Again the highest inhibitory effect was observed when cells were analysed $24 \mathrm{~h}$ after isolation $\left(\mathrm{IC}_{50} \sim 3731\right)$. Further cultivation to $96 \mathrm{~h}$, $120 \mathrm{~h}$ and $192 \mathrm{~h}$ decreased the inhibitory activity $\left(\mathrm{IC}_{50} \sim 5910\right.$, $\left.\mathrm{IC}_{50} \sim 8062, \mathrm{IC}_{50} \sim 57707\right)$ (data not shown). Taken together with the fact that prolonged culturing influences cell morphology and the cell population composition of the sample, these data suggest that cells should be used for experimentation beginning at $24 \mathrm{~h}$ after isolation to enable time-dependent monitoring of the inhibitory effect of the fresh samples and to exclude any further influence from culturing. During the prolonged cultivation no decrease of cell viability was observed.

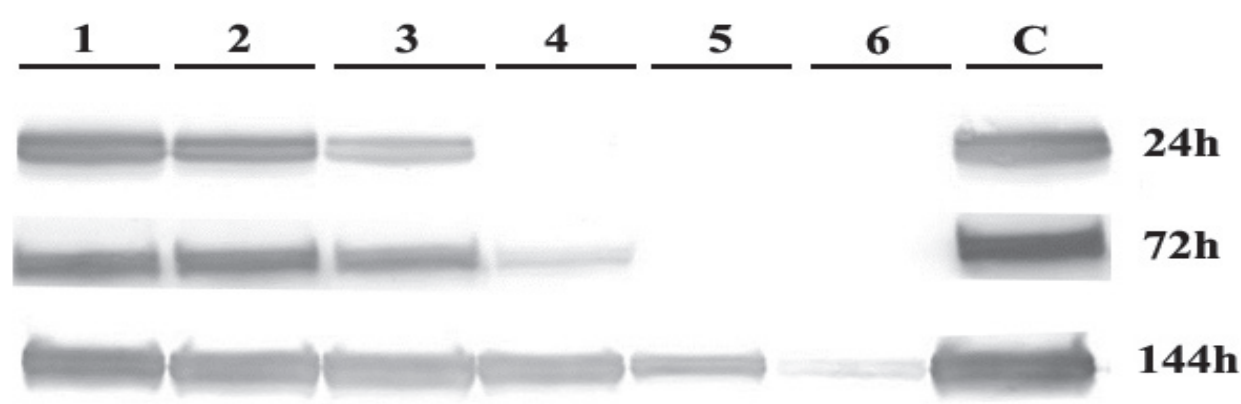

Figure 3. Effect of prolonged cultivation of non-adherent hematopoietic cells on their ability to modulate COX-2 expression. Immunoblotting analysis showing inhibitory activity of hematopoietic cells isolated from bone marrow of AML patient (\# 19) and then cultured for the indicated time points $(24 \mathrm{~h}, 72 \mathrm{~h}, 144 \mathrm{~h})$ before being added to co-cultures with fibroblast spheroids and analysed. Spheroids prepared from MUF fibroblasts (10 ${ }^{4}$ cells/well) were harvested for analysis after $72 \mathrm{~h}$ of co-cultivation with the same portions of isolated hematopoietic cells as shown in Fig. 1 (Lane 1 to 6 added cells $1 \times 10^{3}-3 \times 10^{4} /$ well). Lane C - represents control, the expression of COX-2 in uninfluenced spheroids. 
A

CD45-PE

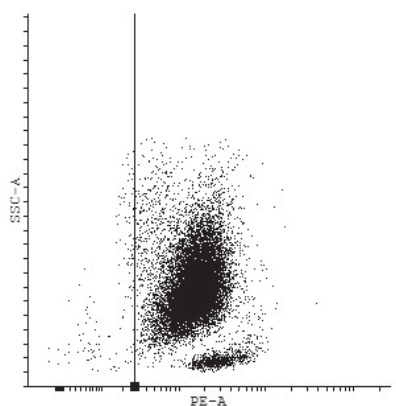

CD20-APC

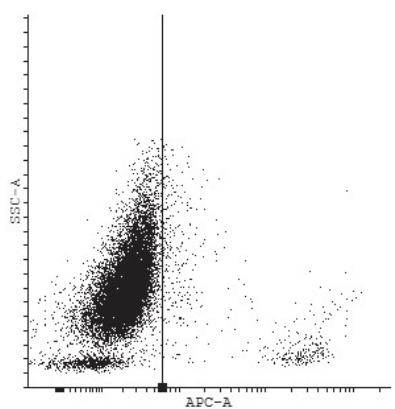

B

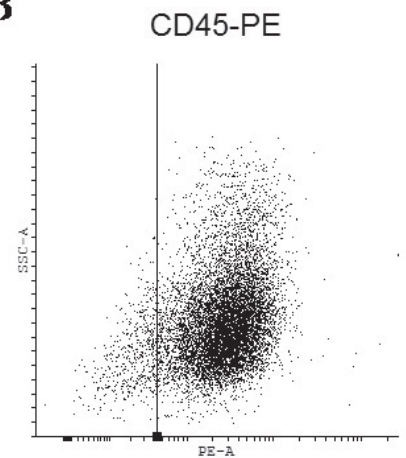

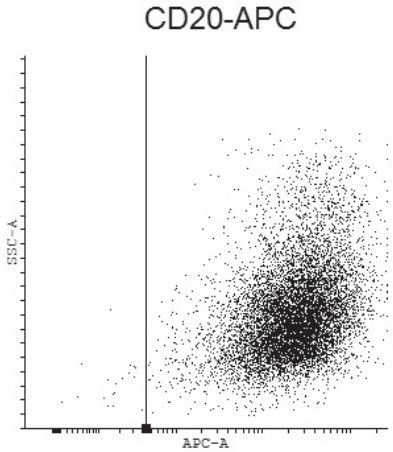

Figure 4. FACS analysis of non-adherent hematopoietic cells derived from a bone marrow sample after prolonged cultivation. The analysis demonstrates composition of a cell culture isolated from a specimen obtained from AML patient (\# 19) after 1 week (A) and 5 weeks (B) of standard cultivation. The appearance of B-cells subpopulation in the culture and its overgrowth is evident after prolonged cultivation. The CD45-PE and CD20-APC antibodies were used for analysis.

In our preliminary work we observed that prolonged culturing of the non-adherent hematopoietic fraction for more than $240 \mathrm{~h}$ may lead to spontaneous overgrowth of a B-cell population. At that time point this overgrowth was evident by phase contrast microscopy, and was confirmed by FACS analysis, as shown in Fig. 4. Since our observation was not associated with B-cell malignancies, we considered it important to exclude interference to the assay from overgrowth of B-cells during the experimentation. We thus selected to routinely perform FACS analysis of all non-adherent hematopoietic cells after the co-culture with spheroids. CD20 was chosen as a characteristic B-cell marker. We observed no B-cell overgrowth during the course of the $96 \mathrm{~h}$ co-culture experiments.

Similarly as in the case of leukemic cell lines, it was necessary to test the possible contribution to COX-2 expression by the sample isolated non-adherent cells. Need of such analysis was supported by evidences from recent studies, which showed that some types of hematological malignancies-such as chronic lymphocytic leukemia, chronic myelogenous leukemia, multiple myeloma, or Hodgkin's and non-Hodgkin's lymphoma-may exhibit marginal levels of COX-2 expression [26]. Therefore, the sample of non-adherent cells was analysed by immunoblotting after standard culture, as well as, after their co-culture with spheroids. We observed no COX-2 expression in standardly cultured cells or in cells co-cultured after $72 \mathrm{~h}$ (data not shown).

Since our results showed that non-adherent cells isolated from bone marrow have the ability to modulate COX-2 expression, we further investigated to what extent the non-adherent cells derived from peripheral blood could possess this capacity. We simultaneously compared non-adherent cells isolated from bone marrow and peripheral blood of the leukemic patient \#1. Non-adherent hematopoietic cells isolated from bone marrow (Fig. 5) showed significantly higher inhibition activity of COX-2 expression $\left(\mathrm{IC}_{50} \sim 3334\right)$ when compared to the value of cells isolated from peripheral blood ( $\left.\mathrm{IC}_{50} \sim 14013\right)$. Moreover, similar results were obtained using cells from peripheral blood of healthy donors, where the $\mathrm{IC}_{50}$ values ranged from 32372 to 162109 (data not shown).

Next we quantitatively evaluated and compared the ability of individual samples of non-adherent hematopoietic cells isolated from bone marrow specimen of leukemic patients either at diagnosis or during treatment of the disease. Table 2 shows the patient data, and Fig. 6 summarizes the differences in $\mathrm{IC}_{50}$ values between controls and patients with malignancy. The non-adherent cells isolated from samples of patients with

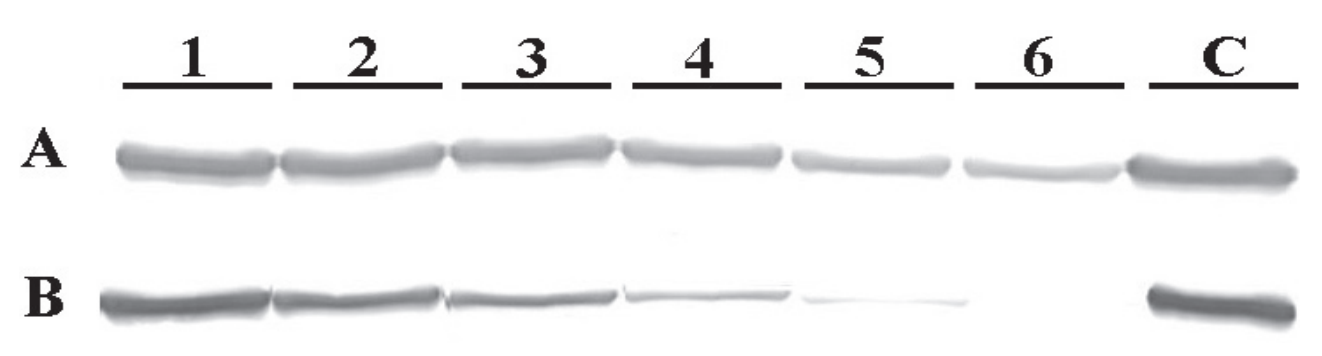

Figure 5. Comparison of COX-2 expression in spheroids after co-cultivation with non-adherent hematopoietic cells isolated from peripheral blood (A) and from bone marrow (B) of follicular lymphoma patient (\# 1). Spheroids prepared from MUF fibroblasts $\left(10^{4}\right.$ cells/well) were harvested for analysis after $72 \mathrm{~h}$ of co-cultivation with the same numbers of isolated hematopoietic cells as shown in Fig. 1. Lane C represents expression of COX-2 in uninfluenced spheroids. 
malignancy showed a mean $\mathrm{IC}_{50}$ value of $20591 \pm 5074$ cells whereas the $\mathrm{IC}_{50}$ for controls was 9 -fold lower at $2284 \pm 601$ cells $(\mathrm{p}<0.01)$. When comparing the samples obtained at diagnosis to those obtained after treatment-for example for relapse or therapy unresponsiveness-their mean $\mathrm{IC}_{50}$ values were 3 -fold higher ( $29046 \pm 8070$ vs. $9600 \pm 2850$ ), but remained statistically not significant due to small sample size.

\section{Discussion}

Within the bone marrow stem cell niche, maintenance of the stem cell pool and production of differentiated blood cells are controlled by reciprocal signaling between stromal and hematopoietic cells [1]. These complex and finely tuned signals may be disrupted by cancerous and precancerous cells. The malignant cell clone tilts the signaling network to favour its proliferation, survival, and migration. One of the manifestations of such altered signaling network is microenvironmental inflammation that promotes proliferation, disrupts the maturation sequences, causes cellular activation, and induces a migratory phenotype [3]. Due to its biological complexity and multiplex nature, such signaling by malignant cells is difficult to measure by classical analytical methods. In order to be able to evaluate alterations or disruptions in the microenvironmental signal web, a more comprehensive and repeatable functional model system is required. Such an analytical system of the hematopoietic cell fraction should use a live cell sample, it should be sensitive, and it should mimic all the biological complexity of mesenchymal cell activation.

In this report, our aim was to find out the basic feasibility of a co-culture method of hematopoietic cells and nemosis-activated fibroblasts as a functional biological ex vivo platform, and to evaluate the usefulness of COX-2 induction as a measure of anti-inflammatory activity of the sample's hematopoietic cell fraction. We show here that a routine normal sample of bone marrow, taken for diagnostic purposes and usually for FACS analysis, is sufficient for further functional ex vivo analysis after depletion of the mesenchymal cell fraction by differential adhesion. The mononuclear cell fraction of the bone marrow sample is preincubated for $24 \mathrm{~h}$ to separate adherent and nonadherent cells. The hematopoietic (non-adherent) fraction is then used for further analysis. Co-cultures of hematopoietic cells and stromal cells have been used to enable hematopoietic cell maintenance and to mimic the bone marrow microenvironment. Usually, however, the focus has been on the reactivity of the hematopoietic fraction [27-35], and not so much on the opposite direction from hematopoietic cells on stromal cells [36-38]. We reported previously that the interactions between leukemic cell lines and fibroblast spheroids induce leukemia cell growth arrest and differentiation [7]. In our current approach we used preformed multicellular fibroblast spheroids as the indicator component to mimic stromal reactivity. We have previously shown that expression of COX-2 is induced in spheroids of human fibroblasts [4], and that this cell-to-cell contact-mediated activation is associated with an increase in

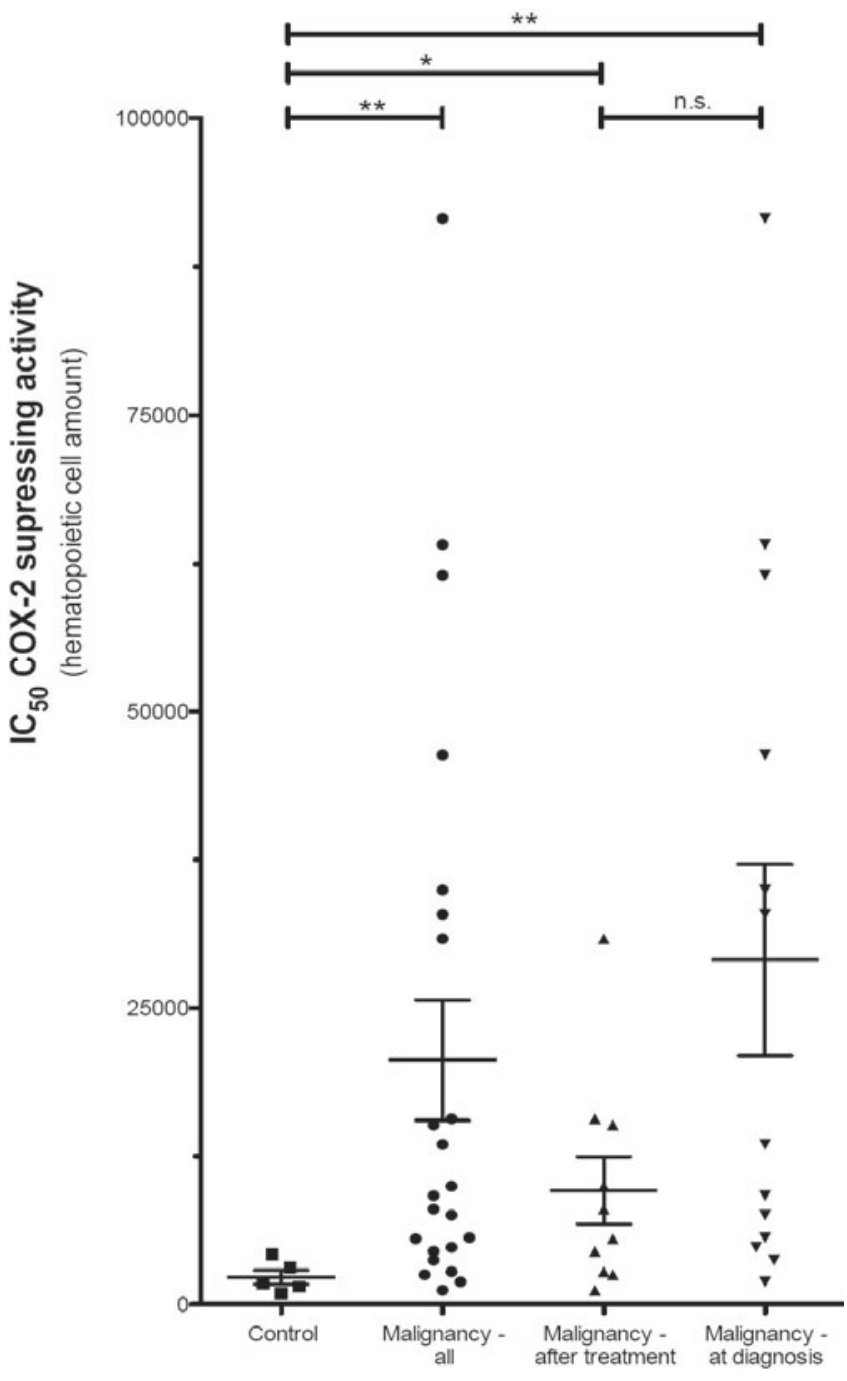

Figure 6. Summary of $\mathrm{IC}_{50}$ values for individual clinical samples. Control group consists of healthy donors or patients without hematological malignancy ( 5 specimens), malignancy after treatment (10 specimens) and malignancy at diagnosis (13 specimens). Horizontal lines represent mean, and vertical lines represent the standard error of the mean (SEM) for each group. ${ }^{\star} \mathrm{p}<0.05$, ${ }^{\star \star} \mathrm{p}<0.01$ between indicated groups, n.s. not significant.

production of a set of inflammatory modulators [5,7]. This process, nemosis, has been linked to inflammation [6], and has been previously used to mimic the stromal reaction in cancer $[7,39,40]$. In the current report we utilized the nemosis reactivity of fibroblasts and COX-2 induction as a sensitive biological indicator of anti-inflammatory activity of hematopoietic cells isolated from bone marrow of leukemia patients.

The co-culture setting permits a full range of biological interplay, including complex paracrine signaling and cell contacts, to take place. The method evaluates the dosedependent effects of hematopoietic bone marrow cells on COX-2 expression in fibroblast spheroids. We observed high variability between patients ranging from potent to almost no 
Table 2. Means of $\mathrm{IC}_{50}$ values of individual patients. Samples in the table are categorized according to the type of leukemia. Moreover, we also take into account if the sample was analysed after treatment or it was a newly diagnosed patient without any treatment $\left(^{\star}\right)$. The group of control samples, composed of specimens derived from healthy donors and patients without hematological malignancy, is summarized in the bottom of the table.

Patients with hematological malignancy ${ }^{*}$, sampled at diagnosis)

\begin{tabular}{|c|c|c|c|c|c|c|}
\hline Patient \# & $\operatorname{Male}(\mathrm{M}) / \operatorname{Female}(\mathrm{F})$ & Age (years) & ICD-10 & Diagnosis & $\mathrm{IC}_{50}$ & \\
\hline 1 & $\mathrm{~F}$ & 60 & C82.0 & Follicular lymphoma grade I & 2499 & \\
\hline 2 & $\mathrm{~F}$ & 21 & C82.0 & Follicular lymphoma grade I & 9153 & * \\
\hline 3 & F & 42 & C82.0 & Follicular lymphoma grade I & 15650 & \\
\hline 4 & $\mathrm{~F}$ & 18 & $\mathrm{C} 82.0$ & Follicular lymphoma grade I & 32889 & * \\
\hline 5 & M & 58 & $\mathrm{C} 82.2$ & Follicular lymphoma grade III, unspecified & 1890 & * \\
\hline 6 & $\mathrm{~F}$ & 62 & $\mathrm{C} 83.0$ & Small cell B-cell lymphoma & 4459 & \\
\hline 7 & M & 8 & C83.0 & Small cell B-cell lymphoma & 7525 & * \\
\hline 8 & M & 10 & C83.5 & Lymphoblastic (diffuse) lymphoma & 8023 & \\
\hline 9 & M & 6 & C83.7 & Burkitt lymphoma & 2757 & \\
\hline 10 & M & 13 & C83.9 & Non-follicular lymphoma, unspecified & 5622 & * \\
\hline 11 & $\mathrm{~F}$ & 59 & C90.0 & Multiple myeloma & 64123 & * \\
\hline 12 & M & 35 & C90.0 & Multiple myeloma & 91561 & * \\
\hline 13 & M & 68 & C91.0 & Acute lymphoblastic leukemia & 4791 & * \\
\hline 14 & $\mathrm{~F}$ & 11 & C91.0 & Acute lymphoblastic leukemia & 30819 & \\
\hline 15 & F & 3 & C91.0 & Acute lymphoblastic leukemia & 34931 & * \\
\hline 16 & $\mathrm{~F}$ & 64 & C91.1 & Chronic lymphocytic leukemia of B-cell type & 46335 & * \\
\hline 17 & M & 67 & C91.1 & Chronic lymphocytic leukemia of B-cell type & 61556 & * \\
\hline 18 & M & 1 & C92.0 & Acute myeloblastic leukemia & 1190 & \\
\hline 19 & $\mathrm{~F}$ & 2 & C92.0 & Acute myeloblastic leukemia & 3731 & * \\
\hline 20 & M & 4 & C92.0 & Acute myeloblastic leukemia & 5516 & \\
\hline 21 & M & 30 & C92.0 & Acute myeloblastic leukemia & 9962 & \\
\hline 22 & $\mathrm{~F}$ & 51 & C92.0 & Acute myeloblastic leukemia & 13492 & * \\
\hline 23 & M & 57 & C92.0 & Acute myeloblastic leukemia & 15126 & \\
\hline
\end{tabular}

Controls

\begin{tabular}{cccccc}
\hline Control \# & Male $(\mathrm{M}) /$ Female(F) & Age (years) & ICD-10 & Diagnosis & IC $_{50}$ \\
\hline C1 & F & 25 & & Healthy donor & 1734 \\
C2 & M & 21 & & Healthy donor & 1475 \\
C3 & F & 31 & D 46.0 & Refractory anemia without ring sideroblasts & 3109 \\
C4 & F & 66 & D46.0 & Refractory anemia without ring sideroblasts & 4202 \\
C5 & M & 6 & & Rheumatoid arthritis & 901 \\
\hline
\end{tabular}

inhibition, suggesting that the method is feasible in detecting sample property-dependent variations. The inflammatory activation in nemosis is induced by a 3 -dimensional cell culture setting and utilizes only biological cell-to-cell signaling without any added external influence. We have shown that induction of fibroblast nemosis involves both cell-cell and paracrine interactions. These components are also altered in leukemic cells due to the disease. Homotypic fibroblastto-fibroblast cell-cell interactions have been shown $[4,41]$ to be involved in the induction of COX-2 in spheroids. We have also shown that paracrine signaling, by for example prostaglandins, can modulate the COX-2 induction [4]. In the current method, hematopoietic cells are placed in co-culture with the fibroblast spheroids, and are able to interact both physically and by soluble signaling. It is thus possible that heterotypic interactions between hematopoietic/leukemic cells in the sample and fibroblasts contribute to the modulation of COX-2 induction. Leukemic cells differently express for example integrins [42], connexins [43], and chemokine receptors [44] all of which can interfere with the regula- 
tion of homotypic cell-cell contact-induced intracellular signaling in fibroblasts. Moreover, leukemia cells actively secrete several paracrine mediators, such as growth factors, cytokines, microparticles, and exosomes, $[45,46]$ that can interfere with the inflammatory COX-2 signal transduction in fibroblast spheroids.

Future work should address the uniformity and quality of the sample, because several sample composition-related aspects may influence its properties. Factors that affect the sample include patient age, pharmacotherapy, and disease type. Also technical variation due to location and technique that is used to harvest the aspirate, initial sample volume, and waiting time before aspirate is forwarded to the laboratory for processing evaluation. On the other hand, it must be stressed that bone marrow aspiration is a routine technique in monitoring leukemia patients, and the accompanying data of FACS analysis can be utilized as further control of sample uniformity.

Based on our current results and on the feasibility to use clinical samples for the assay, we propose fibroblast nemosis as a method for laboratory evaluation and monitoring of leukemia cells' immunomodulatory activity and their ability to modify inflammatory activation. Fibroblast aggregation involves the two functional components: cell-cell contacts and paracrine interactions that may be specifically altered in leukemia. Based on these similarities, we propose that fibroblast nemosis is a prospective sensitive laboratory tool for evaluation and monitoring of leukemia cells' ability to modulate inflammation. In conclusion, our data shows that performing co-culture of bone marrow hematopoietic cells with human fibroblast spheroids is feasible in the clinical diagnostic setting, and the biologicallyinduced and pathogen-unrelated inflammatory reactivity can help evaluate the sample's ability to modulate inflammation. Because the leukemia-stroma crosstalk in the bone marrow modulates the normal signaling network to favour leukemogenesis, this method can provide useful functional biological data to complement the diagnosis or assist for selection of treatment options in specific types of leukemia.

Acknowledgements: The authors thank Mrs Alena Linekova for her skillful technical assistance and Mrs Anna Kovarikova for her expert assistance on flow cytometry. The project was supported by VEGA grant 2/0102/09 from Grant Agency of Slovak Republic and by the University of Helsinki (TULI funding), Finland.

\section{References}

[1] TRIPODO C, SANGALETTI S, PICCALUGA PP, PRAKASH S, FRANCO G et al. The bone marrow stroma in haematological neoplasms - a quilty bystander. Nat Rev Clin Oncol 2011; 8: 456-466. http://dx.doi.org/10.1038/ nrclinonc. 2011.31

[2] KONOPLEVA MY, JORDAN CT. Leukemia stem cells and microenvironment: Biology and therapeutic targeting. J Clin Oncol 2011; 29: 591-599. http://dx.doi.org/10.1200/ ICO.2010.31.0904
[3] BALKWILL FR, MANTOVANI A. Cancer-related inflammation: Common themes and therapeutic opportunities. Semin Cancer Biol 2011;

[4] BIZIK J, KANKURI E, RISTIMAKI A, TAIEB A, VAPAATA$\mathrm{LO} \mathrm{H}$ et al. Cell-cell contacts trigger programmed necrosis and induce cyclooxygenase-2 expression. Cell Death Differ. 2004; 11: 183-95. http://dx.doi.org/10.1038/sj.cdd.4401317

[5] KANKURI E, CHOLUJOVA D, COMAJOVA M, VAHERI A, BIZIK J. Induction of hepatocyte growth factor/scatter factor by fibroblast clustering directly promotes tumor cell invasiveness. Cancer Res. 2005; 65: 9914-22. http://dx.doi. org/10.1158/0008-5472.CAN-05-1559

[6] VAHERI A, ENZERINK A, RASANEN K, SALMENPERA P. NEMOSIS, a novel way of fibroblast activation, in inflammation and cancer. Exp Cell Res. 2009; 315: 1633-1638. http://dx.doi.org/10.1016/j.yexcr.2009.03.005

[7] KANKURI E, BABUSIKOVA O, HLUBINOVA K, SALMENPERÄ P, BOCCACCIO C et al. Fibroblast nemosis arrests growth and induces differentiation of human leukemia cells. Int J Cancer. 2008; 122: 1243-52. http://dx.doi.org/10.1002/ ijc. 23179

[8] ENZERINK A, SALMENPERA P, KANKURI E, VAHERI A. Clustering of fibroblasts induces proinflammatory chemokine secretion promoting leukocyte migration. Mol Immunol. 2009, 46: 1787-1795. http://dx.doi.org/10.1016/ j.molimm.2009.01.018

[9] MAJUMDAR MK, THIEDE MA, HAYNESWORTH SE, BRUDER SP, GERSON SL. Human marrow-derived mesenchymal stem cells (MSCs) express hematopoietic cytokines and support long-term hematopoiesis when differentiated toward stromal and osteogenic lineages. J Hematother Stem Cell Res. 2000; 9: 841-848. http://dx.doi.org/10.1089/ 152581600750062264

[10] PEURA M, BIZIK J, SALMENPERA P, NORO A, KORHONEN $\mathrm{M}$ et al. Bone marrow mesenchymal stem cells undergo nemosis and induce keratinocyte wound healing utilizing the HGF/cMet/PI3K pathway. Wound Repair Regen. 2009, 17: 569-577. http://dx.doi.org/10.1111/j.1524-475X.2009.00507.x

[11] EGYUDOVA K, SILTANEN A, KANKURI E, BIZIK J. Leukemic cells modulate induction of COX-2 in human stromal fibroblasts. Neoplasma. 2011; 58: 525-531. http://dx.doi. org/10.4149/neo 2011 $06 \quad 525$

[12] TSUCHIYA S, YAMABE M, YAMAGUCHI Y, KOBAYASHI $\mathrm{Y}, \mathrm{KONNO} \mathrm{T}$ et al. Establishment and characterization of a human acute monocytic leukemia cell line (THP-1). Int J Cancer 1980; 26: 171-176. http://dx.doi.org/10.1002/ ijc. 2910260208

[13] KOEFFLER HP, GOLDE DW. Acute myelogenous leukemia: a human cell line responsive to colony-stimulating activity. Science 1978; 200: 1153-1154. http://dx.doi.org/10.1126/ science. 306682

[14] SUNDSTROM C, NILSSON K. Establishment and characterization of a human histiocytic lymphoma cell line (U-937). Int J Cancer 1976; 17: 565-577. http://dx.doi.org/10.1002/ ijc.2910170504

[15] GALLAGHER R, COLLINS S, TRUJILlO J, MCCREDIE, AHEARN $\mathrm{M}$ et al. Characterization of the continuous, dif- 
ferentiating myeloid cell line (HL-60) from a patient with acute promyelocytic leukemia. Blood 1979; 54: 713-733.

[16] OHYASHIKI K, OHYASHIKI JH, SANDBERG AA. Cytogenetic characterization of putative human myeloblastic leukemia cell lines (ML-1, -2, -3): origni of the cells. Cancer Res. 1986; 46: 3642-3647.

[17] TSUJI-TAKAYAMA K, KAMIYA T, NAKAMURA S, MATSUO Y, ADACHI T et al. Establishment of multiple leukemia cell lines with diverse myeloid and/or megakaryoblastoid characteristics from a single $\mathrm{Ph} 1$ positive chronic myelogenous leukemia blood sample. Hum Cell 1994; 7: 167-171.

[18] SCHNEIDER U, SCHWENK HU, BORNKAMM G. Characterization of EBV-genome negative "null“ and „T“ cell lines derived from children with acute lymphoblastic leukemia and leukemic transformed non-Hodgkin lymphoma. Int J Cancer 1977; 19: 621-6. http://dx.doi.org/10.1002/ijc.2910190505

[19] KLEIN E, KLEIN G, NADKARNI JS, NADKARNI JJ, WIGZELL H et al. Surface IgM-kappa specificity on a Burkitt lymphoma cell in vivo and in derived culture lines. Cancer Res. 1968; 28: 1300-1310.

[20] KLEIN G, GIOVANELLA B, WESTMAN A, STEHLIN JS, MUMFORD D An EBV-genome-negative cell line established from an American Burkitt lymphoma; receptor characteristics. EBV infectibility and permanent conversion into EBVpositive sublines by in vitro infection. Intervirology 1975; 5 : 319-334.

[21] LOZZIO CB, LOZZIO BB. Human chronic myelogenous leukemia cell-line with positive Philadelphia chromosome. Blood 1975; 45: 321-334.

[22] KOHNO S, MINOWADA J, SANDBERG AA. Chromosome evolution of near-haploid clones in an established human acute lymphoblastic leukemia cell line (NALM-16). J Natl Cancer Inst 1980; 64: 485-493.

[23] NILSSON K, SUNDSTRÖM C Establishment and characteristics of two unique cell lines from pateints with lymphosarcoma. Int J Cancer 1974; 13: 808-823. http://dx.doi. org/10.1002/ijc.2910130609

[24] DREXLER HG. (2000) The leukemia-lymphoma cell line factsbook, San Diego: Academic Press.

[25] BARTOSH TJ, YLOSTALO JH, MOHAMMADIPOOR A, BAZHANOV N, COBLE K et al. Aggregation of human mesenchymal stromal cells (MSCs) into 3D spheroids enhances their antiinflammatory properties. Proc Natl Acad Sci USA 2010; 107: 13724-13729. http://dx.doi.org/10.1073/ pnas. 1008117107

[26] BERNARD MP, BANCOS S, SIME PJ, PHIPPS RP. Targeting cyclooxygenase-2 in haematological malignancies: rationale and promise. Curr Pharm Des. 2008; 14: 2051-60. http:// dx.doi.org/10.2174/138161208785294654

[27] GLENJEN NI, HATFIELD K, BRUSERUD Ø. Coculture of native human acute myelogenous leukemia blasts with fibroblasts and osteoblasts results in an increase of vascular endothelial growth factor levels. Eur J Haematol. 2005; 74: 24-34. http://dx.doi.org/10.1111/j.1600-0609.2004.00333.x

[28] SAMUDIO I, FIEGL M, MCQUEEN T, CLISE-DWYER K, ANDREEFF M. The Warburg effect in leukemia-stroma cocultures is mediated by mitochondrial uncoupling associated with uncoupling protein 2 activation. Cancer Res. 2008; 68: 5198-205. http://dx.doi.org/10.1158/0008-5472.CAN-08$\underline{0555}$

[29] MANSHOURI T, ESTROV Z, QUINTAS-CARDAMA A, BURGER J, ZHANG Y et al. Bone marrow stroma-secreted cytokines protect JAK2(V617F)-mutated cells from the effects of a JAK2 inhibitor. Cancer Res. 2011; 71: 3831-40. http://dx.doi.org/10.1158/0008-5472.CAN-10-4002

[30] EDELMANN J, KLEIN-HITPASS L, CARPINTEIRO A, FUHRER A, SELLMANN L et al. Bone marrow fibroblasts induce expression of PI3K/NF-kappaB pathway genes and a pro-angiogenic phenotype in CLL cells. Leuk Res. 2008; 32: 1565-72. http://dx.doi.org/10.1016/j.leukres.2008.03.003

[31] NEFEDOVA Y, LANDOWSKI TH, DALTON WS. Bone marrow stromal-derived soluble factors and direct cell contact contribute to de novo drug resistance of myeloma cells by distinct mechanisms. Leukemia 2003; 17: 1175-82. http:// dx.doi.org/10.1038/sj.leu.2402924

[32] GUPTA D, TREON SP, SHIMA Y, HIDESHIMA T, PODAR $\mathrm{K}$ et al. Adherence of multiple myeloma cells to bone marrow stromal cells upregulates vascular endothelial growth factor secretion: therapeutic applications. Leukemia 2001; 15: 1950-61. http://dx.doi.org/10.1038/sj.leu.2402295

[33] DØSEN-DAHL G, MUNTHE E, NYGREN MK, STUBBERUD $\mathrm{H}$, HYSTAD ME et al. Bone marrow stroma cells regulate TIEG1 expression in acute lymphoblastic leukemia cells: role of TGFbeta/BMP-6 and TIEG1 in chemotherapy escape. Int J Cancer. 2008; 123: 2759-66. http://dx.doi.org/10.1002/ijc.23833

[34] WEISBERG E, WRIGHT RD, McMILLIN DW, MITSIADES C, RAY A et al. Stromal-mediated protection of tyrosine kinase inhibitor-treated BCR-ABL-expressing leukemia cells. Mol Cancer Ther. 2008; 7: 1121-9. http://dx.doi.org/10.1158/ 1535-7163.MCT-07-2331

[35] LUIKART SD, SACKRISON JL, MANIGLIA CA. Bone marrow matrix modulation of HL-60 phenotype. Blood 1987; 70: 1119-23.

[36] RYNINGEN A, WERGELAND L, GLENJEN N, GJERTSEN BT, BRUSERUD $\varnothing$. In vitro crosstalk between fibroblasts and native human acute myelogenous leukemia (AML) blasts via local cytokine networks results in increased proliferation and decreased apoptosis of AML cells as well as increased levels of proangiogenic Interleukin 8. Leuk Res. 2005; 29: 185-96. http://dx.doi.org/10.1016/j.leukres.2004.06.008

[37] GLENJEN N, ERSVAER E, RYNINGEN A, BRUSERUD $\varnothing$. In vitro effects of native human acute myelogenous leukemia blasts on fibroblasts and osteoblasts. Int J Cancer 2004; 111: 858-67. http://dx.doi.org/10.1002/ijc.20353

[38] PLANDER M, UGOCSAI P, SEEGERS S, ORSO E, REICHLE A et al. Chronic lymphocytic leukemia cells induce anti-apoptotic effects of bone marrow stroma. Ann Hematol. 2011; 90: 1381-90. http://dx.doi.org/10.1007/ s00277-011-1218-Z

[39] RASANEN K, SALMENPERA P, BAUMANN M, VIRTANEN I, VAHERI A. Nemosis of fibroblasts is inhibited by benign HaCaT keratinocytes but promoted by malignant HaCaT cells. Mol Oncol. 2008; 2: 340-8. http://dx.doi.org/10.1016/ j.molonc.2008.09.002 
[40] RASANEN K, VIRTANEN I, SALMENPERA P, GRENMAN $\mathrm{R}$, VAHERI A. Differences in the nemosis response of normal and cancer-associated fibroblasts from patients with oral squamous cell carcinoma. PLoS One 2009; 4:e6879. http://dx.doi. org/10.1371/journal.pone.0006879

[41] SALMENPERA P, KANKURI E, BIZIK J, SIREN V, VIRTANEN I et al. Formation and activation of fibroblast spheroids depend on fibronectin-integrin interaction. Exp Cell Res. 2008; 314: 3444-52. http://dx.doi.org/10.1016/ j.yexcr.2008.09.004

[42] VAN DER VELDE-ZIMMERMAN D, SMITS AJ, VERDAASDONK MA, RADEMAKERS LH, WERNER $\mathrm{N}$ et al. beta1-Integrins dominate cell traffic of leukemic cells in human bone-marrow stroma. Int J Cancer 1996; 66: 225-33. http:// dx.doi.org/10.1002/(SICI) 1097-0215(19960410)66:2<225:: AID-IJC15>3.0.CO;2-B
[43] FOSS B, TRONSTAD KJ, BRUSERUD O. Connexin-based signaling in acute myelogenous leukemia (AML). Biochim Biophys Acta. 2010 Jan; 1798: 1-8.

[44] FERRETTI E, BERTOLOTTO M, DEAGLIO S, TRIPODO C, RIBATTI D et al. A novel role of the CX3CR1/CX3CL1 system in the cross-talk between chronic lymphocytic leukemia cells and tumor microenvironment. Leukemia 2011; 25: 1268-77. http://dx.doi.org/10.1038/leu.2011.88

[45] TAVERNA S, FLUGY A, SAIEVA L, KOHN EC, SANTORO A et al. Role of exosomes released by chronic myelogenous leukemia cells in angiogenesis. Int J Cancer 2011; [Epub ahead of print]

[46] MINEO M, GARFIELD SH, TAVERNA S, FLUGY A, DE LEO $\mathrm{G}$ et al. Exosomes released by K562 chronic myeloid leukemia cells promote angiogenesis in a src-dependent fashion. Angiogenesis 2011; [Epub ahead of print] 